\title{
Opportunities and Threats for Chinese Newspaper Media in the Omnimedia Era*
}

\author{
HU Xiao-juan \\ Dalian University of Technology, Dalian, Liaoning province, China
}

\begin{abstract}
Chinese Newspaper Media in the Omnimedia Era are faced with opportunities and threats brought by media ecological reconstruction. However. Newspaper media still have the advantages of circulation and readership. Through combing the basic situation and the main advantage of newspaper media development, this paper summarizes communication practice and future development of newspaper media. It is found that newspaper media should build a series of self-controlled new media platforms and integrate superiorities. What's more, based on newspaper-oriented, newspaper media should strengthen the core feature of media and maintain the influence and communication value
\end{abstract}

Keywords: newspaper transformation, omnimedia, media convergence, internet thinking

\section{Introduction}

Facing the media ecological reconstruction brought by media convergence, the mobile Internet era, big data and micro-communication, the norm of newspaper media in the past has been broken, facing a new adjustment. Chinese newspaper industry entered into a new historical period with both opportunities and threats. This article summarizes the basic situation and the main advantage of newspaper media development. By analyzing newspaper media communication practice, this paper try to explore what the newspaper media can achieve in media convergence, newspaper industry transformation and to provide some proposals about how to face with the main problems and the future development for newspaper. Also, newspaper media should actively adapt to the new ecology communication, using the Internet thinking to promote the transformation of the newspaper industry and to meet opportunities and challenges.

\section{Basic Situation and Frame Advantage of Chinese Newspaper Media}

There's a lot of talk about newspaper fate, such as "winter theory", "inflection point" and "the fade of newspaper". It is even predicted that more than two-thirds of newspaper will be "shut down or turning" in 2018 (Ma \& Hu, 2016).

In recent years, newspaper recession trend deepens in the face of new media environment and

\footnotetext{
* Acknowledgements: this paper is fund by "Dalian University of Technology Introduction of Talent Research Project 2 (DUT18RC (4) 003)".

HU Xiao-juan, Ph.D., Lecturer, Master supervisor, Department of Humanities and Social Sciences, Dalian University of Technology.
} 
communication pattern, with circulation and advertising "bluff type" sliding, suspension of publication increasing year by year.

However, the latest figures from SAPPRFT showed that there were 1,894 kinds of newspapers published throughout the country in 2016. In addition, according to the released results of the 15th national reading survey, adult newspaper reading rate was $37.6 \%$ in 2017 , while the average daily reading time of adult citizens in China was 12 minutes in the traditional paper media.

Therefore, the advantages of circulation and readership remain in newspaper media. As the main representative of traditional media, the newspaper is an important part of media ecology with unique frame advantage, which is communication capability, guiding force, credibility and influence based on the authority, ideological and profundity in content. Newspaper serves as not only information source for new media, but also provide confirmation and evaluation to expand information depth and set the agenda for new media. What's more, newspaper's investigative journalism, in-depth reporting and comments, have built the remarkable influence and quality of print media platform with unique strength and ideological, which is the soul of the newspaper.

American scholar Philip Meyer (2004) who has put forward "the fade of newspaper", however he also set forth newspaper's influence economy. He believed that the main product of newspaper is influence rather than news or information.

Newspaper's frame advantage has profound influence on audience. In the media field, the development of technology and the change of media environment highlight the importance of content in the competition. In most cases, only professional journalist from newspaper can better finish some high quality reports since they have unique advantages in terms of money, organization and logistics.

With the diversification of information access channel, releasing information is no longer media privilege. Instead, how to estimate, interpret and verify information thereby providing authoritative interpretation and in-depth reporting becomes especially important. As a result, news competition mainly focused on the right of information interpretation rather than news sources in traditional sense.

\section{Chinese Newspaper Transformation Practice}

The change of information production mode driven by new media technology has dispelled the monopoly power of information production and release. Traditional newspapers should meet the "new normal" of newspaper industry by transforming actively, inspecting old problems with new eyes. Actually, positive view is inclined to transformation of newspaper industry development, with both opportunities and threat.

Newspaper media has carried out deep reform of newspaper industry and exploration of effective profit model.

Newspaper industry reform follows the survival of the fittest, untenable newspaper withdraw from the market, reducing homogenous and vicious competition. Also, newspaper promotes cross-border integration and structural adjustment to enlarge scale effect, cultivating several new media group with powerful strength. Some newspapers have established special new media centers leveraging new media companies' commercial operation. For example, People's Daily has far beyond the scope of a newspaper, but a collection site of microblog, wechat, app, mobile news, network television etc, which basically covers all kinds of existing communication form (Yuan, 2014). What's more, People's Daily App is downloaded more than 5 million after online two months. The 
Paper App adapts to new spread in mobile Internet era, whose users has far more than its newspaper's readership.

Deep reform has provided an internal impetus for a new round of newspaper industry prosperity and a strong guarantee for the newspaper smooth development.

With the increasing dominance of mobile communication and mobile terminals, newspapers' traditional business model "content + advertising" is unsustainable. New business model based on print media is expanding in release services and reading forms, exploring newspaper space of the second and third-tier cities that have not yet penetrated into new media, and exerting the potential of metropolitan newspapers.

This year, Henan Daily Newspaper Group effectively responded to newspaper profit dilemma by launching diversified operation with 65\% non-newspaper revenue of finance, advertising, hotel and education (Xie, 2018). Newspaper actively participated in the construction of database engineering, and gradually found the connection point of the Internet and related industries by means of exploiting big data resource.

\section{Future Development of Chinese Newspaper}

The omnimedia age deeply influenced the transformation of newspaper media, what can be achieved and how to deal with the main problems better, the future development for newspaper cannot ignore its core content.

\section{Reinvention of New Technology for Providing Quality and Irreplaceable Content}

News content has been presented in endless ways driven by technology innovation. In 2016, 12 newspapers in China jointly set up VR news laboratory to explore new forms of information. Particularly, China's media convergence cloud realized one-stop solution to media technology problems. Big data operation, artificial intelligence application and new content production are no longer conundrum.

Newspapers set up omnimedia editing platforms one after another using new media technology, such as “central kitchen” of People’s Daily, which breaks away from integration draft library through the whole process and constructs complete content production line, realizing content sharing of entire industry even cross-industry. Finally, it leads a batch of media to reform and innovate in the direction of "once collection, diverse generation and multiple transmission".

Leveraging big data and cloud computing technology, users' needs can be precisely analyzed, which improves the pertinence of news reporting and service. Turn your audience into users and embrace collaborative innovation to bring content video presentation, precise push and multi-channel marketing.

In the future, newspaper media need to identify themselves and differentiate in content and communication. Besides, it must be familiar with the way news will be consumed in times to come, thus creating unique products.

\section{Promoting Media Convergence with Internet Thinking}

As early as 2014, the first year of media convergence in China, integration of traditional media and emerging media has become a national strategy (Jia, Yin \& Deng, 2014).

Media convergence centers on exploring new forms of expression suitable for the Internet (Li \& Zhou, 2014). Professor Chen Li dan (2014) pointed out that "Internet thinking” needs to use communication features of the Internet to think deeply about media convergence.

Media convergence is no longer the shift between traditional media and new media, but the share of advantage resource and cooperation of reconstituted regulation under New Barrel Theory. Anyhow, the evolution 
of media form will not change the value of news.

In fact, media mergence era brings both vigor and challenges to media safety. Study of media convergence pays too much attention to technology, strategy and effects, neglecting the contact of media convergence and media security. Therefore, more attention need to be paid to the information security maintenance, new media public opinion and policy regulations.

\section{Conclusion}

China's newspaper media faced both opportunities and threats for in the omnimedia era. Based on newspapers' remained advantages, newspapers have to do more different things than simply do the same things better.

Newspaper media should strive to build a series of self-controlled new media platforms and integrate superiorities. Meanwhile newspaper should provide a mingled space for traditional business and new media, ascending discourse power and influence in the field of new media public opinion.

Maybe the feasible framework of future newspaper industry is mainly newspaper-oriented, leaving media as a platform for influence and public opinion, strengthening the core feature of media and maintain the influence and communication value.

\section{References}

Chen, L. D. (2014). Promote media convergence with Internet thinking. Contemporary Communications, 6, 1.

Jia, Z. J., Yin, C., \& Deng, X. Q. (2014). Research on current situation and countermeasures of Chinese media convergence. Science-Technology \& Publication, 10, 137.

Li, L. R., \& Zhou, K. W. (2014). Media convergence: Old routines and new exploration. Journalist, 8, 18-19.

Ma, C. J., \& Hu, P. (2016). Research on the dilemma and countermeasures of traditional newspapers in the new media environment. Today's Massmedia, 12, 84-85.

Philip, M. (2004). The vanishing newspaper: Saving journalism in the information age. Columbia: University of Missouri Press.

Xie, M. (2018). The top ten practical cases of China's newspaper transformation in 2017. Sohu, 1(21). Retrieved from http://www.sohu.com/a/218054549_654813.

Yuan, S. J. (2014). Joy and worry in the transformation of Chinese newspaper industry. China news \& publishing network, 10(28). Retrieved from http://news.xinhuanet.com/newmedia/2014-10/28/c_127150731.htm. 